\title{
Lactobacillus plantarum inoculation delays decomposition of alfalfa silage under adverse ensiling conditions by regulating bacterial community composition
}

\section{Fengyuan Yang}

Zhengzhou University https://orcid.org/0000-0002-5296-7235

Yanping Wang ( $\square$ wyp@zzu.edu.cn )

Zhengzhou University

Shanshan Zhao

Zhengzhou University

\section{Yuan Wang}

Zhengzhou University

\section{Research}

Keywords: Lactobacillus plantarum, Spoilage microorganism, Alfalfa silage, Adverse ensiling condition, High-throughput sequencing

Posted Date: April 21st, 2020

DOI: https://doi.org/10.21203/rs.3.rs-22777/v1

License: (c) (1) This work is licensed under a Creative Commons Attribution 4.0 International License.

Read Full License 


\section{Abstract \\ Background}

The objective of this study was to investigate the mechanism of Lactobacillus plantarum (L. plantarum) involved in improving fermentation quality of naturally ensiled alfalfa under poor conditions.

\section{Results}

High-moisture wilted alfalfa was ensiled without inoculants (CK) or with inoculation of two L. plantarum additives (LPI and LPII). The pH and fermentation products of silage were investigated, and the bacterial community compositions were analyzed. The L. plantarum inoculants significantly enhanced the lactic acid fermentation in terms of promotions in $\mathrm{pH}$ decline, lactic acid accumulation, and Lactobacillus abundance for both periods. At $90 \mathrm{~d}$, silage in $\mathrm{CK}$ exhibited a high $\mathrm{pH}$, a loss in dry matter, and a high concentration of ammoniacal nitrogen. The inoculations of $L$. plantarum significantly inhibited the growth of Clostridia, and reduced ammoniacal nitrogen concentration in silage $(P<0.05)$.

\section{Conclusions}

Inoculation with L. plantarum improved the fermentation quality of alfalfa silage and inhibited the growth of spoilage microorganisms, and further delayed decomposition of alfalfa silage under adverse ensiling conditions.

\section{Background}

Ensiling is an anaerobic microbial-based fermentation process, dominated by lactic acid bacteria (LAB), which produce the lactic acid (LA) required for $\mathrm{pH}$ decline and harmful microbe inhibition. It has long been a common method for forage preservation (Eikmeyer et al., 2013). Alfalfa, a widely cultivated and economically valuable pasture plant, is an important forage crop used for ensiling worldwide (Dunière et al., 2013). However, it can be hard to ensile owing to its high buffering capacity (BC) and lack of water soluble carbohydrates (WSCs) (Nkosi et al., 2016), especially when the moisture concentration exceeds $70 \%$, resulting in clostridial fermentation (Coblentz and Muck, 2012). Wilting to an appropriate dry matter (DM) (300-400 g/kg fresh weight (FW)) is recommended before ensiling to prevent effluent production (Dunière et al., 2013). However, high precipitation in some areas can make it difficult to wilt the forage before ensiling. Alfalfa is a perennial herb that is harvested in spring, summer, and autumn in most areas in China other than the north. At the end of spring or early summer, mid-eastern and southern China have abundant rainwater, and the alfalfa ensiled for over two or three months will reach high temperatures during summer. Sudden rainfall and high air humidity may cause extended wilting periods, which affect characteristics of the ensiling material. Sustained high temperatures during the ensiling process may also affect the stability of fermentation. 
The microbial community plays an important role in the fermentation process and is likely to be impacted by multiple factors, such as ensiling conditions, inoculants, and epiphytic microorganisms of the fresh forage (Guan et al., 2018; Kasmaei et al., 2017). The development of PCR-based techniques enables us to define the microbial communities more accurately, and a larger variation in the microbiota in alfalfa silages than in cereal silages has been documented (McAllister et al., 2018). Inoculations of Lactobacillus plantarum could enhance the acidification of silage and adaption to a low pH environment, which contributes to the inhibition of competing microorganisms and effectively improves silage quality. Thus, L. plantarum is the most commonly used bacterial inoculant in forage ensiling studies (Oliveira et al., 2017). During ensiling, L. plantarum enhances LA fermentation and survives and adapts to the silage environment (Guo et al., 2018; Ogunade et al., 2018; Yang et al., 2019). However, the fermentation quality of the silage varies owing to different factors, such as BC, water activity, and presence of epiphytic microbes. The latter can differ owing to several factors, such as forage type, climatic conditions, and irrigation level. Adverse ensiling conditions, such as extremely high temperature, high humidity, and soil incorporation, can result in the poor fermentation of alfalfa silage. Under good conditions, silage without L. plantarum inoculation can produce a good fermentation quality, with a decline in $\mathrm{pH}$, abundant LA accumulation, and sufficient LAB counts. However, few studies have examined the effects of $L$. plantarum on alfalfa silage fermentation quality when poor fermentation conditions occur.

The aim of this study was to investigate the mechanism of L. plantarum in improving fermentation quality of naturally ensiled alfalfa under the poor conditions that commonly occur in spring and summer ensiling in China. Yellow River-irrigated alfalfa was harvested during the high precipitation season when the relative humidity exceeded $80 \%$, and ensiled for $90 \mathrm{~d}$ after a 1 -d wilting with or without $L$. plantarum inoculation. Particular attention was paid to bacterial communities, fermentation properties, and their interactions in silage.

\section{Methods}

\subsection{Materials and silage preparation}

Fresh alfalfa was harvested at the early bloom stage in Zhengzhou, Henan Province (temperate monsoon climate, $34.76^{\circ} \mathrm{N}, 113.65^{\circ} \mathrm{E}$, altitude $110.4 \mathrm{~m}$ above sea level), and wilted for $24 \mathrm{~h}$. The wilted material was chopped into 1-2-cm lengths. For inoculant preparation, L. plantarum YX was isolated from the Yaxin alfalfa ensiling additive (Yaxin Biotechnology Co., Ltd., Taiwan, China) and L. plantarum A345, an alfalfa silage epiphytic strain, was isolated from Shanxi, China. The L. plantarum strains were cultured in MRS medium at $30^{\circ} \mathrm{C}$ for $12 \mathrm{~h}$. Then, the culture was centrifuged at $12,000 \mathrm{~g}$ for $10 \mathrm{~min}$ at $4^{\circ} \mathrm{C}$. The precipitate was mixed with distilled water to an $\mathrm{OD}_{600}$ of 0.8 .

Approximately $500 \mathrm{~g}$ for each of three replicates of the chopped alfalfa were treated with the following: (1) distilled water control (CK); (2) $1 \times 10^{6}$ colony forming units (cfu)/g of L. plantarum YX (LPI); and (3) $1 \times 10^{6} \mathrm{cfu} / \mathrm{g}$ of L. plantarum A345 (LPII). All replicates were packed into polyethylene plastic bags, 
vacuumed, sealed with a vacuum sealer (P-290, Shineye, Dongguan, China), and ensiled at ambient temperature for 30 and $90 \mathrm{~d}$.

\subsection{Analysis of fermentation products}

The AOAC Method 934.01 (1990) was used for DM determination. Subsamples were dried in an oven at $65^{\circ} \mathrm{C}$ for $48 \mathrm{~h}$ and pulverized to pass through a 1-mm screen using a laboratory knife mill (FW100, Taisite Instrument Co. Ltd., Tianjin, China). The WSCs were measured using anthrone colorimetry (Murphy, 1958).

Other subsamples of silage $(10 \mathrm{~g})$ were diluted with $90 \mathrm{ml}$ of distilled water and filtered through a 0.45$\mu \mathrm{m}$ membrane. The $\mathrm{pH}$ was measured using a $\mathrm{pH}$ meter. The organic acid contents were determined using high-performance liquid chromatography (Waters Alliance e2695, Waters, MA, USA). Carbomix HNP 10:8\% (7.8 $\mathrm{mm} \times 300 \mathrm{~mm} \times 10 \mu \mathrm{m})$ was used as the stationary phase, and the column temperature was maintained at $55^{\circ} \mathrm{C}$. The injected sample volume was $10 \mu \mathrm{l}$. The mobile phase composition was $0.0254 \%$ sulfuric acid. The mobile phase was filtered through a $0.45-\mu \mathrm{m}$ pore size, $47-\mathrm{mm}$ diameter nylon membrane and degassed before use. The flow rate of the mobile phase was $0.6 \mathrm{ml} / \mathrm{min}$. The detection wavelength for samples was $214 \mathrm{~nm}$ using a UV detector. The ammoniacal nitrogen $\left(\mathrm{NH}_{3}-\mathrm{N}\right)$ level was determined using Berthelot colorimetry (Broderick and Kang, 1980). The BC was determined using the hydrochloric acid-sodium hydroxide method (Playne et al., 2010). The fermentation coefficient of alfalfa silage was predicted using the formula of Addah et al. (2011).

\subsection{Bacterial community analyses}

Total DNAs were extracted using a Bacterial DNA Kit D3350-02 (Omega Biotek, Norcross, GA, USA). The purity levels and concentrations of DNAs were evaluated by $1 \%$ agarose gel electrophoresis. The PCR amplifications of the V3-V4 regions of the bacterial 16SrDNA gene were performed using Primer $F$ (Illumina adapter sequence 1 + CCTACGGGNGGCWGCAG) and Primer R (Illumina adapter sequence 2 + GACTACHVGGGTATCTAATCC). The PCR products were extracted from a $2 \%$ agarose gel. The amplicon sequencing of 16SrDNA was conducted using the Miseq platform (Genesky Bio-Tech Co. Ltd., Shanghai, China) after the purification and quantification of the PCR products. All the raw reads were checked using FLASH2, and low quality sequences (quality scores below 20) were discarded according to the QIIME quality control process (version 1.7.0). Operational taxonomic units were clustered using Uparse (Uparse v7.0.1001, http://www.drive5.com/uparse/). The analysis of taxonomy assignment of representative sequences was performed using the Ribosome Database Project (Cole et al., 2009).

\subsection{Statistical analyses}

The statistical analysis of the fermentation products was performed using IBM SPSS version 21.0 (SPSS Inc., Chicago, IL, USA). The effects of different treatments were evaluated by one-way analysis of variance, with Duncan's multiple range tests. The alpha diversity of the bacterial communities was calculated using mothur (version 1.9.1). The beta diversity analyses and correlation analyses between bacterial compositions and environmental factors were performed using R software (version 2.15.3). 


\section{Results}

\subsection{Characteristics of ensiling material before ensiling}

The wilted alfalfa had pH of 6.06, DM of $266 \mathrm{~g} / \mathrm{kg} \mathrm{FW}$, WSC concentration of $17.56 \mathrm{~g} / \mathrm{kg} \mathrm{DM}$, and a high $\mathrm{BC}$ of $460 \mathrm{mEq} / \mathrm{kg} \mathrm{DM}$. Organic acid and $\mathrm{NH}_{3}-\mathrm{N}$ were not detected.

\subsection{Effects of $L$. plantarum on fermentation properties of alfalfa silage}

Organic acid and $\mathrm{NH}_{3}-\mathrm{N}$ contents, as well as the $\mathrm{pH}$ level, of alfalfa silage inoculated with or without $L$. plantarum strains are shown in Table 1 . The $L$. plantarum inoculants effectively accelerated the LA fermentation and acetic acid (AA) accumulation, resulting in a lower $\mathrm{pH}$ compared with the CK group ( $P<$ $0.001)$ at $30 \mathrm{~d}$; and the enhanced LA accumulation was significantly greater in the LPII group $(P<0.001)$. For 90-d silage, increase in $\mathrm{pH}$ level and $\mathrm{NH}_{3}-\mathrm{N}$ concentration, reduction in LA and WSC concentration, as well as formation of propionic acid (PA), occurred compared with 30-d silage. Significantly higher $\mathrm{pH}(P<$ $0.001)$ and $\mathrm{NH}_{3}-\mathrm{N}$ accumulation $(P=0.001)$, as well as a significant loss in $\mathrm{DM}(P=0.017)$ were apparent in the CK compared with the inoculated groups. Silage in the LPII group had better fermentation quality compared with other groups, indicated by a relatively low $\mathrm{pH}$, high LA and AA concentrations, and inhibition of $\mathrm{NH}_{3}-\mathrm{N}$ formation. The significantly lower WSC residual $(P=0.007)$ also indicated a more abundant fermentation in the LPII group.

\subsection{Effects of $L$. plantarum on bacterial community composition}

High-throughput analysis was used to determine the bacterial diversity in alfalfa silage, and the valid sequences were clustered into 552 operational taxonomic units based on a $97 \%$ sequence identity. Richness and diversity indices of the bacterial communities, represented by observed species, the Chao 1 and the Shannon indexes, respectively, are shown in Fig. 1A-C. The richness of the bacterial community decreased after ensiling for $30 \mathrm{~d}$ compared with the ensiling material, and then increased at $90 \mathrm{~d}(P=$ 0.005). The diversity of the bacterial community decreased after ensiling $(P=0.006)$. The diversity of the bacterial community in silage in LPII slightly and non-significantly increased at $90 \mathrm{~d}$ compared with 30-d silage $(P=0.1)$.

The principal coordinate analysis (PCOA) clearly reflected the variation within the bacterial community (Fig. 2). The clear separation between bacterial communities of the ensiling material and alfalfa silage indicated a shift after ensiling. Divisions in the plots representing silage with and without inoculants for both periods indicated that the distribution of the bacterial community was shifted by L. plantarum inoculations. The distribution of the bacterial communities among the three replications within LPII was more similar compared to those within CK and LPI at $30 \mathrm{~d}$. Although the Shannon indexes were similar between 30-d and 90-d silage (Fig. 1C), divisions in the plots representing silage for the two periods indicated a variation within the bacterial community. 
Proteobacteria (52.14\%) was the predominant phylum in the ensiling material, followed by Firmicutes (30.33\%) (Fig. 3A). Firmicutes became the predominant phylum after ensiling, except for the CK group at $30 \mathrm{~d}$. Inoculation increased the relative abundance of Firmicutes in the 30-d silage compared with $\mathrm{CK}$, and the relative abundance of Firmicutes was greater in LPII (84.74\%) than LPI (64.62\%). At the genus level, Pseudomonas (15.35\%), Exiguobacterium (12.36\%), Massilla (14.15\%), and Planococcus (8.00\%) dominated the epiphytic bacterial community of alfalfa, while abundance levels of these genera reduced after ensiling. Low abundance of LAB species was exhibited in the alfalfa epiphytic bacterial community, including Lactobacillus (1.36\%), Weissella (0.70\%), Lactococcus $(0.07 \%)$, Pediococcus $(0.01 \%)$, and Leuconostoc $(<0.01 \%)$. A complex bacterial community composition was exhibited in CK in the 30-d silage, with the prevalent genera being Enterobacter (38.54\%), Weissella (11.59\%), Garciella (10.42\%), and Lactococcus (9.59\%) (Fig. 3B). However, Lactobacillus, the predominant genus in LPI and LPII (57.82\% and $82.19 \%$, respectively), only exhibited a relative abundance of $2.05 \%$ in CK at $30 \mathrm{~d}$. Inoculation inhibited the growth of Enterobacter at 30 d, with the lowest relative abundance for LPII (10.20\%). The relative abundance of Enterobacter became similar among the three treatments in the $90-\mathrm{d}$ silage $(14.96 \%$ in $\mathrm{CK}, 11.60 \%$ in LPI, and $14.83 \%$ in LPII). Garciella became a prevalent genus at $90 \mathrm{~d}$, with relative abundance of $34.95 \%$ in CK, $38.38 \%$ in LPI, and $24.04 \%$ in LPII. The relative abundance of Lactobacillus in the inoculated silage decreased, and Clostridia including Clostridium_XIVa and Clostridium_sensu_stricto grew in all treatments at $90 \mathrm{~d}$ compared with 30-d silage. An inhibitory effect against Clostridium_XIVa was apparent in LPII compared with the other two groups in 90-d silage.

LefSe was performed to further explore the variations in the bacterial communities among the treatments (Fig. 4). Significantly higher abundances of species of Enterobacter, Lactococcus, and Enterococcus were observed in CK at $30 \mathrm{~d}$. Lactobacillus species grew well in LPII in 30-d silage. At $90 \mathrm{~d}$, the relative abundance of some species belonging to spoilage genus Clostridium and pathogenic genus Listeria were significantly higher in the CK group. Although silage in LPIl effectively inhibited the growth of Clostridium_XIVa (Fig. 3B) (13.42\% in CK, 6.67\% in LPI, and 0.67\% in LPII, respectively), it showed a relatively poorer inhibition against some Clostridia genera with low abundance.

Clostridium_sensu_stricto, for instance, a genus belonging to family Clostridiaceae_1, exhibited relative abundances of $1.94 \%, 1.88 \%$, and $3.23 \%$ in CK, LPI, and LPII in $90-d$ silage, respectively.

\subsection{Correlation analysis of the bacterial community with fermentation products}

Mantel tests were performed to reveal the relationships between bacterial community compositions at different taxon levels and silage properties (Table 2). Results indicated significant correlations between fermentation properties and the bacterial community composition $(P<0.05)$ at different taxon levels, except for $\mathrm{pH}$ value and bacterial community composition at phylum level. Spearman's correlation analysis indicated that the $\mathrm{pH}$ value and LA concentration had significant correlations with richness and diversity indices of the bacterial communities $(P<0.05)$. A strong negative correlation was found between AA concentration and the Shannon index $(P<0.05)$. Meanwhile, the number of observed species and the 
Chao1 index of the bacterial community showed positive correlations with $\mathrm{PA}$ and $\mathrm{NH}_{3}-\mathrm{N}$ concentrations, and negative correlations with WSC concentration $(P<0.05)$.

Spearman's correlations further illustrated the relationships between bacterial genera and silage properties for different periods (Fig. $5 \mathrm{~A}$ and B). Lactobacillus was positively correlated with $L A(r=0.92$ at $30 \mathrm{~d}$ and 0.87 at $90 \mathrm{~d})$, and negatively correlated with $\mathrm{pH}(\mathrm{r}=-0.92$ at $30 \mathrm{~d}$ and -0.88 at $90 \mathrm{~d})$ for both periods. Positive correlations were found between $\mathrm{NH}_{3}-\mathrm{N}$ and two genera at $30 \mathrm{~d}(P<0.05)$, Rosenbergiella and Bifidobacterium. The $\mathrm{NH}_{3}-\mathrm{N}$ was negatively correlated with Nocardioides, Methylobacterium, and Prevotella in 30-d silage $(P<0.05)$. The $\mathrm{NH}_{3}-\mathrm{N}$ was positively correlated with a series of nitrogen-fermenting genera at $90 \mathrm{~d}$, including Anaerotruncus, Peptoniphilus, and genera belonging to Clostridia (Clostridium_XIVa, Clostridium_XI, and Finegoldia) $(P<0.05)$. Other genera also showed positive correlations with $\mathrm{NH}_{3}-\mathrm{N}$ at $90 \mathrm{~d}$, including Weissella, Eremococcus, Brevibacillus, Vagococcus, Anaerococcus, Enterococcus, and Propionibacterium $(P<0.05)$. Nocardioides and Methylobacterium retained their negative correlations with $\mathrm{NH}_{3}-\mathrm{N}$ at 90 d. Another genus belonging to Nocardioidaceae, Marmoricola, was also negatively correlated with $\mathrm{NH}_{3}-\mathrm{N}$. Negative correlations with $\mathrm{NH}_{3}-\mathrm{N}$ were also apparent for the acid-producing genus Lactobacillus, nitrate-reducing genera Pantoea and Exiguobacterium, putrescine-fermenting genus Anaerovorax, and other genera, including Planomicrobium, Acinetobacter, Kocuria, and Janibacter, with unknown functions in the ensiling process.

\section{Discussion}

\subsection{Characteristics of wilted alfalfa}

Adverse conditions during harvesting and ensiling could result in decomposition of silage. In this study, Yellow River-irrigated alfalfa was chosen as the ensiling material, and was harvested at the early bloom stage during the high precipitation season. Although the wilting period was extended compared with previous studies (Li et al., 2018a, b), the DM $(266 \mathrm{~g} / \mathrm{kg} \mathrm{FW}$ ) was still lower than the recommended content (300-400 g/kg FW). This might due to the high precipitation during the harvest season. Frequent rainfall resulting in high air humidity slowed the moisture loss during wilting. As reported by Agarussi et al. (2019) and Tao et al. (2017), wilting decreased the WSC concentration and crude protein content in fresh alfalfa. The 24 -h wilting may have exacerbated the lack of WSC $(17.56 \mathrm{~g} / \mathrm{kg} \mathrm{DM})$ in this study. The WSC of the ensiling material was lower than $50 \mathrm{~g} / \mathrm{kg} \mathrm{DM}$, which was insufficient for adequate fermentation during ensiling (Ni et al., 2018). The BC was still high after wilting in this study. Frequent rainfall might increase the incorporation of soil in fresh alfalfa during harvest, resulting in an increase in BC (Weinberg and Ashbell, 2003). This might stimulate the epiphytic aerobic microorganisms to remain active for an extended period and so reduce the quantity of WSCs for further LAB fermentation. The low fermentation coefficient $(26.9<35)$ also suggested that the material was too hard to ensile naturally (Ke et al., 2015).

\subsection{Effects of $L$. plantarum on fermentation properties of alfalfa silage}


Inoculation with $L$. plantarum had a positive effect on fermentation properties in terms of lower $\mathrm{pH}$ and higher LA accumulation. Similar effects were also reported by Wang et al. (2019) and Yang et al. (2019), in which LA fermentation was accelerated by L. plantarum inoculants in Moringa oleifera leaves and in alfalfa silage, respectively. The LPII exhibited more abundant LA fermentation than LPI. This might be explained by better adaption of the alfalfa epiphytic inoculant in LPII. Good adaption to the alfalfa ensiling environment of the inoculant aids in improvement of silage quality (Zhao et al., 2020). The AA concentrations increased with L. plantarum inoculations at $30 \mathrm{~d}$. The AA is a promoter of aerobic stability during the ensiling process (Schmidt and Kung, 2010) and an effective inhibitor of fungi (Le Lay et al., 2016). This enhancement in AA accumulation might help with $\mathrm{pH}$ decline and reduction in microbial richness at early stages of ensiling. Although inoculation enhanced LA fermentation in the 30-d silage, $\mathrm{pH}$ in the silage was still above ideal level $(<4.20)$. The increase in $\mathrm{pH}$ in 90 -d silage also suggested that LA fermentation was insufficient to stabilize the ensiled mass. The insufficient LA fermentation might be due to a lack of available substrate and high BC of the ensiling material.

The LA to AA ratio became much lower at $90 \mathrm{~d}$ in all treatments, indicating reduction in LA fermentation in the silage. The PA contents in silage were also out of the acceptable range of $1-10 \mathrm{~g} / \mathrm{kg} \mathrm{DM}$ (Agarussi et al., 2019). The $\mathrm{NH}_{3}-\mathrm{N}$ is considered a representative of amino acid deamination and decarboxylation (Scherer et al., 2015), which generally reduce the nutritional value of silage. The remarkable increase in $\mathrm{pH}$ value and $\mathrm{NH}_{3}-\mathrm{N}$ concentration, as well as the loss in $\mathrm{DM}$ in $\mathrm{CK}$ at $90 \mathrm{~d}$ indicate potential decomposition of silage. The delay in decomposition with L. plantarum inoculation was shown by the lower $\mathrm{pH}$ and $\mathrm{NH}_{3}-\mathrm{N}$ concentration, higher LA residual, and good DM maintenance. The $\mathrm{NH}_{3}-\mathrm{N}$ concentration in LPII was significantly lower compared with other treatments, indicating better protein maintenance with the inoculant.

Notably, the $\mathrm{NH}_{3}-\mathrm{N}$ concentration increased in LPI $(P<0.001)$, but the LA accumulation and pH decline were greater, compared with the $\mathrm{CK}$ group. Effects of Clostridia and plant proteolytic enzymes may be typical causes of $\mathrm{NH}_{3}-\mathrm{N}$ accumulation (Kung and Shaver, 2001). Tao et al. (2012) reported that most plant proteolytic enzymes in alfalfa silage showed greater activities at $\mathrm{pH}$ 5.0-6.0, which could explain the higher $\mathrm{NH}_{3}-\mathrm{N}$ concentration in LPI. Plant proteolytic enzymes tended to be more active at the $\mathrm{pH}$ level in LPI (5.60) than in CK (6.10). Although LPI and LPII had similar pH values (5.60 and 5.50, respectively), LPII showed low $\mathrm{NH}_{3}-\mathrm{N}$ formation. This might result from the greater acidogenic capability of the inoculant in LPII in terms of higher LA and AA concentrations, which contributed to an increased inhibition of proteolytic microorganisms.

\subsection{Effects of L. plantarum on bacterial community of alfalfa silage}

Although richness of bacterial community decreased compared with the ensiling material at the early stage of ensiling, the richness flourished at $90 \mathrm{~d}$. Similar trends were also reported by Zheng et al. (2017) in direct-cut alfalfa silage with and without LAB inoculant and sugar and by Keshri et al. (2018) in untreated corn silage, in which richness of the bacterial community decreased at the early stage of 
ensiling compared with the alfalfa material, and later increased during the ensiling process. Consistent with the study of $\mathrm{Ni}$ (2017a), diversity of the bacterial community decreased after ensiling. Inoculation slightly reduced diversity of the bacterial community. Although the Shannon indexes were similar between the 30-d and 90-d silage, the PCoA showed variation within the bacterial community. The clear separation between bacterial communities of the ensiling material and alfalfa silage indicated a shift after ensiling, consistent with previous studies (Ni et al., 2017b; Yang et al., 2019). Divisions between the plots representing silage with and without inoculants indicated that the distribution of the bacterial community was shifted by L. plantarum inoculations, which could explain the differences in fermentation quality (Ni et al., 2018). The distribution of the bacterial communities among the three replications within LPII was more similar compared with those within LPI for both periods. The more stable bacterial community distribution in LPII might result from its stronger LA fermentation represented by the highest LA concentration (Table 1) and Lactobacillus abundance (Fig. 3B) among the treatments for both periods.

Proteobacteria $(52.14 \%)$ was the most predominant phylum in the wilted alfalfa, while abundance of Proteobacteria and Firmicutes reversed after being ensiled for $90 \mathrm{~d}$, with Firmicutes dominating the bacterial community. Kershiri et al. (2018) concluded that environmental conditions that developed during ensiling favor the selection of species of the phylum Firmicutes that flourish under low $\mathrm{pH}$ and anaerobic conditions. The increasing abundance of Firmicutes at $30 \mathrm{~d}$ in inoculated silage might indicate an acceleration of the LA fermentation process in the presence of $L$. plantarum. Acceleration of the LA fermentation with $L$. plantarum inoculation was also shown at the genus level. The major bacteria involved in LA fermentation of silage belong to the genera Lactobacillus, Pedicoccus, Weissella, and Leuconostoc (Ni et al., 2018; Pang et al., 2011). Low abundance of these genera was exhibited in the wilted alfalfa before ensiling, and aerobic microorganisms dominated the bacterial community. This was consistent with the results of Tao et al. (2017), in which a long period of wilting decreased the LAB count and promoted growth of aerobes in alfalfa before ensiling.

A series of Clostridia genera grew in the 90-d silage. Clostridia may lead to excessive protein degradation, DM loss, and butyric acid (BA) production in silage, and further promote the growth of other less acidtolerant spoilage microorganisms (Wang et al., 2019). Thus, they are undesirable in silage. Clostridiales (64.47\%) dominated the bacterial community in CK at $90 \mathrm{~d}$ at the order level. Inoculation with $L$. plantarum effectively inhibited the dominance of Clostridiales (48.27\% in LPI and $29.26 \%$ in LPII, respectively), which further reduced $\mathrm{NH}_{3}-\mathrm{N}$ formation, maintained the $\mathrm{DM}$ (Table 1), and inhibited less acid-tolerant Listeria pathogens in silage (Fig. 4). Although Clostridia is a major producer of BA in silage, presence of BA was not detected in our study. This might result from the activity of BA-utilizing microbes in silage. Flythe and Russell (2004) reported that some Clostridia could produce large amounts of AA apart from BA. This might explain the high AA concentration in CK at $90 \mathrm{~d}$. A high abundance of Garciella, an anaerobic and thermophilic bacterium belonging to Clostridiales (Miranda-Tello et al., 2003), was apparent in the 90-d silage. A high abundance level of Garciella was also reported by Zhang et al. (2018) in alfalfa silage ensiled at a high temperature of $40^{\circ} \mathrm{C}$. The excessively high temperature during July 
(with the highest temperature over $40^{\circ} \mathrm{C}$ during the day time) might be one cause of Garciella growth. Spearman's correlation analysis showed a weak relationship between Garciella and $\mathrm{NH}_{3}-\mathrm{N}$ (Fig. 5B). In all, the current evidence is insufficient to indicate a certain role of Garciella in the ensiling process.

Although L. plantarum inoculation promoted Lactobacillus abundance in silage, it failed to stabilize the abundance of Lactobacillus at $90 \mathrm{~d}$. The overlong period of wilting before ensiling may have exacerbated the poor stability of the bacterial community. The period of wilting reduced the WSC concentration available for LA fermentation, and led to a lower LAB population before ensiling. Excessively high temperature might be another factor influencing stability of the bacterial community. The high temperature might stimulate the growth of thermophilic microorganisms that compete with LAB. An effect of high temperature on stability of the bacterial community was also reported in maize silage (Guan et al., 2018). Further research is needed to evaluate the influence of these factors on silage fermentation.

\subsection{Relationships between bacterial community and fermentation properties}

Recent studies illustrated an interaction of bacterial community and silage properties (McAllister et al., 2018). Mantel tests revealed close correlations of the $\mathrm{pH}, \mathrm{LA}, \mathrm{AA}, \mathrm{PA}, \mathrm{NH}_{3}-\mathrm{N}$, and WSC with bacterial community composition. The $\mathrm{pH}$ and LA affected both the richness and diversity of bacterial community. The concentration of AA remained stable for both periods (Table 1) regardless of the shift in bacterial abundance. This is consistent with its poor relationship with bacterial richness illustrated by Spearman correlations. There was a negative correlation between AA and diversity of the bacterial community, possibly due to an inhibitory effect of AA toward some bacterial species. The PA and $\mathrm{NH}_{3}-\mathrm{N}$ had positive correlations with bacterial richness, but this did not affect diversity of the bacterial community. A probable explanation is that $\mathrm{PA}$ and $\mathrm{NH}_{3}-\mathrm{N}$ were mainly produced by some specific species in silage, so concentrations of these products mainly depended on the number of their producers rather than the composition of microbes. The WSC was negatively correlated with bacterial abundance. This is predictable, because WSC is consumed with the growth of microbes, as a main nutrient source of microbes in silage.

Spearman's correlation analysis illustrated some potential spoilage genera in alfalfa silage. Genera that correlated with $\mathrm{NH}_{3}-\mathrm{N}$ differed between the two periods. This indicates a potential shift in the main promoters of $\mathrm{NH}_{3}-\mathrm{N}$ formation during ensiling. At $30 \mathrm{~d}$, Rosenbergiella and Bifidobacterium were potential promoters of $\mathrm{NH}_{3}-\mathrm{N}$ formation. Rosenbergiella is a genus belonging to Enterobacteriaceae. An abundance of Bifidobacterium was also reported in direct-cut alfalfa silage with a high $\mathrm{NH}_{3}-\mathrm{N}$ concentration (Zheng et al., 2017). At $90 \mathrm{~d}$, presence of Clostridia lead to increasing formation of $\mathrm{NH}_{3}-\mathrm{N}$ by fermenting amino acids (Flythe and Russell, 2004). Spearman's correlation analysis illustrates a series of $\mathrm{NH}_{3}-\mathrm{N}$ producers belonging to Clostridia, including Clostridium_XIVa, Clostridium_XI, and Finegoldia. Another two nitrogenutilizing genera, Anaerotruncus and Peptoniphilus, were also considered to promote $\mathrm{NH}_{3}-\mathrm{N}$ formation. 
There is little evidence concerning the role of Eremococcus in silage fermentation. One recent study reported dominance of Eremococcus in the anodic biofilms in air-cathode microbial fuel cells (Zhang et al., 2016). In air-cathode microbial fuel cells, electroactive microorganisms, mainly in the form of anodic biofilms, accelerate the rate of electrochemical oxidation of complex organic substrates (Borole et al., 2011). This indicates the potential capability of Eremococcus in oxidizing organic materials; however, this study did not shown that oxidation by Eremococcus could occur under acidic conditions. Thus, further research is needed to explore its role in the ensiling system. Anaerococcus is a butyrate-producing saccharolytic genus, and so may exhibit synergy with Clostridium during ensiling - this might explain its positive correlation with $\mathrm{NH}_{3}-\mathrm{N}$. Some species of Vagococcus were reported to exhibit capability for arginine hydrolysis (Teixeria et al., 1997), which might aggravate protein degradation in silage. In this study, Weissella was outcompeted by Lactobacillus following L. plantarum inoculation, and exhibited low abundance in the inoculated groups. This might explain the positive correlation between Weissella and $\mathrm{NH}_{3}-\mathrm{N}$. A higher abundance of Weissella was exhibited in $\mathrm{CK}$, for which the $\mathrm{NH}_{3}-\mathrm{N}$ concentration was significantly higher than the other treatments. Propionibacterium requires complex nutrition, including multiple vitamins and an abundant nitrogen source to produce PA and AA from glucose and other carbohydrates (Rogers et al., 2006). Accumulation of $\mathrm{NH}_{3}-\mathrm{N}$ might promote its growth and fermentation metabolism, resulting in the high PA concentrations in the 90-d silage. Brevibacillus was also positively correlated with $\mathrm{NH}_{3}-\mathrm{N}$, but its role in ensiling is currently unclear.

The L. plantarum inoculation induced a rapid drop in $\mathrm{pH}$ at $30 \mathrm{~d}$, which would inhibit proteolytic bacteria and contribute to true protein preservation (Weinberg and Muck, 1996). This was also illustrated by the inhibitory effect against Clostridiales in the inoculated silage and the negative correlation between Lactobacillus and $\mathrm{NH}_{3}-\mathrm{N}$. Although L. plantarum inoculation aided in protein preservation in this study, it failed to stabilize the abundance of Lactobacillus at $90 \mathrm{~d}$. This demonstrated that Inoculation of $L$. plantarum alone might be insufficient to overcome the adverse conditions during ensiling. And other strategies combining with L. plantarum inoculation might help to stablilize the fermentation quality. For instance, ensiling the freshly harvested alfalfa in combine with excessively wilted stover could help to reach an appropriate moisture for LA fermentation. Apart from Lactobacillus, correlation analysis suggests that some other genera may also contribute to protein preservation. However, the roles of these genera in the ensiling process remain little understood, and more evidence is needed to elucidate their relationships with protein preservation in silage.

\section{Conclusions}

High precipitation in spring and summer during harvest and high temperatures during the ensiling process of alfalfa are universal in mid-eastern and southern China, as well as other areas with similar climatic characteristics. Inoculations of $L$. plantarum significantly promoted $\mathrm{pH}$ decline, LA accumulation, and Lactobacillus abundance under such poor fermentation conditions in alfalfa silage. Growth of Clostridia were inhibited after $L$. plantarum inoculations, which further reduced $\mathrm{NH}_{3}-\mathrm{N}$ formation in the 90d silage. Thus, L. plantarum improved the fermentation properties of alfalfa silage under adverse ensiling 
conditions by enhancing LA fermentation and inhibiting the growth of spoilage microorganisms, and further delayed the decomposition of silage.

\section{Abbreviations}

Lactobacillus plantarum, L. plantarum; LA, lactic acid; LAB, lactic acid bacteria; BC, buffering capacity; WSC, water soluble carbohydrate; $\mathrm{DM}$, dry matter; $\mathrm{FW}$, fresh weight; $\mathrm{NH}_{3}-\mathrm{N}$, ammoniacal nitrogen; $\mathrm{AA}$, acetic acid; PA, propionic acid; LDA, linear discriminant analysis; BA, butyric acid.

\section{Declarations}

Ethics approval and consent to participate

Not applicable.

Consent for publication

Not applicable.

Availability of data and material

The datasets used and/or analysed during the current study are available from the corresponding author on reasonable request.

Competing interests

Not applicable.

Funding

This work was supported by the National Natural Science Foundation of China (31772672). The sponsor had no involvement in study design; in the collection, analysis and interpretation of data; in the writing of the report; or in the decision to submit the article for publication.

Authors' contributions

Yang Fengyuan: Conceptualization, Formal analysis, Writing - Original Draft, Visualization. Wang Yanping: Writing - Review \& Editing, Supervision, Project administration, Funding acquisition. Zhao Shanshan: Methodology, Validation, Investigation. Wang Yuan: Resources.

Acknowledgments

We thank the National Natural Science Foundation of China (31772672) for the financial support for this study, and International Science Editing ( http://www.internationalscienceediting.com ) for editing this manuscript.. 


\section{Preference for color}

Online only.

\section{References}

Addah W, Baah J, Groenewegen P, Okine EK, McAllister TA. Comparison of the fermentation characteristics, aerobic stability and nutritive value of barley and corn silages ensiled with or without a mixed bacterial inoculant. Can. J. Anim. Sci. 2011; 91(1): 133-146.

Agarussi MCN, Pereira OG, Silva VPD, Leandro ES, Santos SA. Fermentative profile and lactic acid bacterial dynamics in non-wilted and wilted alfalfa silage in tropical conditions. Mol Biol Rep. 2019; 46(1): 451-460.

AOAC. Official Methods of Analysis, 15th ed. Association of Official Analytical Chemists, Arlington, VA. 1990.

Borole AP, Reguera G, Ringeisen B, Wang ZW, Feng Y, Kim BH. Electroactive biofilms: current status and future research needs. Energy Environ Sci. 2011; 4: 4813-4834.

Broderick GA, Kang JH. Automated simultaneous determination of ammonia and total amino acids in ruminal fluid and in vitro media. J Dairy Sci. 1980; 63: 64-75.

Coblentz WK, Muck RE. Effects of natural and simulated rainfall on indicators of ensilability and nutritive value for wilting alfalfa forages sampled before preservation as silage. J Dairy Sci. 2012; 95(11): 66356653.

Cole JR, Wang Q, Cardenas E, Fish J, Chai B, Farris RJ, Kulam-Syed-Mohideen AS, McGarrell DM, Marsh T, Garrity GM, Tiedje JM. The Ribosomal Database Project: improved alignments and new tools for rRNA analysis. Nucleic Acids Res. 2009; 37(Database issue): 141-145.

Duniere L, Sindou J, Chaucheyras-Durand F, Chevallier I, Thevenot-Sergentet D. Silage processing and strategies to prevent persistence of undesirable microorganisms. Anim Feed Sci Tech. 2013; 182(1-4): 115.

Eikmeyer FG, Kofinger P, Poschenel A, Junemann S, Zakrzewski M, Heinl S, Mayrhuber E, Grabherr R, Puehler A, Schwab H, Schluter A. Metagenome analyses reveal the influence of the inoculant Lactobacillus buchneri CD034 on the microbial community involved in grass ensiling. J Biotechnol. 2013; 167(3): 334-343.

Flythe MD, Russell JB. The effect of $\mathrm{pH}$ and a bacteriocin (bovicin HC5) on Clostridium sporogenes MD1, a bacterium that has the ability to degrade amino acids in ensiled plant materials. FEMS Microbiol Ecol. 2004; 47: 215-222. 
Guan H, Yan YH, Li XL, Li XM, Shuai Y, Feng GY, Ran QF, Cai YM, Li Y, Zhang XQ. Microbial communities and natural fermentation of corn silages prepared with farm bunker-silo in Southwest China. Bioresource Technol. 2018; 265: 282-290.

Guo XS, Ke WC, Ding WR, Ding LM, Xu DM, Wang WW, Zhang P, Yang FY. Profiling of metabolome and bacterial community dynamics in ensiled Medicago sativa inoculated without or with Lactobacillus plantarum or Lactobacillus buchneri. Sci Rep-Uk. 2018; 8.

Kasmaei KM, Dicksved J, Sporndly R, Uden P. Separating the effects of forage source and field microbiota on silage fermentation quality and aerobic stability. Grass Forage Sci. 2017; 72(2): 281-289.

Ke WC, Yang FY, Undersander DJ, Guo XS. Fermentation characteristics, aerobic stability, proteolysis and lipid composition of alfalfa silage ensiled with apple or grape pomace. Anim Feed Sci Tech. 2015; 202: 12-19.

Keshri J, Chen YR, Pinto R, Kroupitski Y, Weinberg ZG, Sela S. Microbiome dynamics during ensiling of corn with and without Lactobacillus plantarum inoculant. Appl Microbiol Biot. 2018; 102(9): 4025-4037.

Kung LJ, Shaver R. Interpretation and use of silage fermentation analysis reports. Focus on Forage. 2001; 3: $1-5$.

Le Lay C, Coton E, Le Blay G, Chobert JM, Haertle T, Choiset Y, Van Long NN, Meslet-Cladiere L, Mounier J. Identification and quantification of antifungal compounds produced by lactic acid bacteria and propionibacteria. Int. J. Food Microbiol. 2016; 239: 79-85.

Li X, Tian J, Zhang Q, Jiang Y, Wu Z, Yu Z. Effects of mixing red clover with alfalfa at different ratios on dynamics of proteolysis and protease activities during ensiling. J Dairy Sci. 2018a; 101: 1-11.

Li J, Yuan X, Desta ST, Dong Z, Mugabe W, Shao T. Characterization of Enterococcus faecalis JF85 and Enterococcus faecium Y83 isolated from Tibetan yak (Bos grunniens) for ensiling Pennisetum sinese. Bioresource Technol. 2018b; 257: 76-83.

McAllister TA, Duniere L, Drouin P, Xu S, Wang Y, Munns K, Zaheer R. Silage review: Using molecular approaches to define the microbial ecology of silage. J Dairy Sci. 2018; 101(5): 4060-4074.

Miranda-Tello E, Fardeau ML, Sepúlveda J, Fernández L, Cayol JL, Thomas P, Ollivier B. Garciella nitratireducens gen. nov., sp. nov., an anaerobic, thermophilic, nitrateand thiosulfate-reducing bacterium isolated from an oilfield separator in the Gulf of Mexico. Int J Syst Evol Micr. 2003; 53(5): 1509-1514.

Murphy RP. A method for the extraction of plant samples and the determination of total soluble carbohydrates. J. Sci. Food Agric. 1958; 9(11): 714-717.

Ni K, Minh T, Tu T, Tsuruta T, Pang H, Nishino N. Comparative microbiota assessment of wilted Italian ryegrass, whole crop corn, and wilted alfalfa silage using denaturing gradient gel electrophoresis and 
next-generation sequencing. Appl Microbiol Biot. 2017a; 101(4): 1385-1394.

Ni KK, Wang FF, Zhu BG, Yang JX, Zhou GA, Pan Y, Tao Y, Zhong J. Effects of lactic acid bacteria and molasses additives on the microbial community and fermentation quality of soybean silage. Bioresource Technol. 2017b; 238: 706-715.

Ni KK, Zhao JY, Zhu BG, Su RN, Pan Y, Ma JK, Zhou GA, Tao Y, Liu XR, Zhong J. Assessing the fermentation quality and microbial community of the mixed silage of forage soybean with crop corn or sorghum. Bioresource Technol.2018; 265: 563-567.

Ogunade IM, Jiang Y, Cervantes AAP, Kim DH, Oliveira AS, Vyas D, Weinberg ZG, Jeong KC, Adesogan AT. Bacterial diversity and composition of alfalfa silage as analyzed by Illumina MiSeq sequencing: Effects of Escherichia coli 0157:H7 and silage additives. J Dairy Sci. 2018; 101(3): 2048-2059.

Oliveira AS, Weinberg ZG, Ogunade IM, Cervantes AAP, Arriola KG, Jiang Y, Kim D, Li XJ, Goncalves MCM, Vyas D, Adesogan AT. Meta-analysis of effects of inoculation with homofermentative and facultative heterofermentative lactic acid bacteria on silage fermentation, aerobic stability, and the performance of dairy cows. J Dairy Sci. 2017; 100(6): 4587-4603.

Pang HL, Qin GY, Tan ZF, Li ZW, Wang YP, Cai YM. Natural populations of lactic acid bacteria associated with silage fermentation as determined by phenotype, $16 \mathrm{~S}$ ribosomal RNA and recA gene analysis. Syst Appl Microbiol. 2011; 34(3): 235-241.

Playne MJ, Mcdonald P. The buffering constituents of herbage and of silage. J. Sci. Food Agric. 2010; 17: 264-268.

Rogers P, Chen JS, Zidwick MJ. Organic Acid and Solvent Production, in: Dworkin, M. (Eds), The Prokaryotes. New York: Springer; 2006. p. 611-615.

Scherer R, Gerlach K, Sudekum KH. Biogenic amines and gamma-amino butyric acid in silages: Formation, occurrence and influence on dry matter intake and ruminant production. Anim Feed Sci Tech. 2015; 210: 1-16.

Schmidt RJ, Kung L. The effects of Lactobacillus buchneri with or without a homolactic bacterium on the fermentation and aerobic stability of corn silages made at different locations. J Dairy Sci. 2010; 93(4): 1616-1624.

Tao L, Guo XS, Zhou H, Undersander DJ, Nandety A. Short communication: Characteristics of proteolytic activities of endo- and exopeptidases in alfalfa herbage and their implications for proteolysis in silage. $J$ Dairy Sci. 2012; 95(8): 4591-4595.

Tao L, Zhou H, Zhang N, Si B, Tu Y, Ma T, Diao Q. Effects of different source additives and wilt conditions on the $\mathrm{pH}$ value, aerobic stability, and carbohydrate and protein fractions of alfalfa silage. Anim Sci J. 2017; 88: 99-106. 
Teixeira LM, Carvalho MGS, Merquior VLC, Steigerwalt AG, Facklam RR. Phenotypic and genotypic characterization of vagococcus fluvialis, including strains isolated from human sources. J Clin Microbiol. 1997; 35(11): 2778-2781.

Wang C, He LW, Xing YQ, Zhou W, Yang FY, Chen XY, Zhang Q. Fermentation quality and microbial community of alfalfa and stylo silage mixed with Moringa oleifera leaves. Bioresource Technol. 2019; 284: 240-247.

Weinberg ZG, Ashbell G. Engineering aspects of ensiling. Biochem Eng J. 2003; 13: 181-188.

Weinberg ZG, Muck RE. New trends in development and use of inoculants for silage. FEMS Microbiol Rev. 1996; 19: 53-68.

Yang LL, Yuan XJ, Li JF, Dong ZH, Shao T. Dynamics of microbial community and fermentation quality during ensiling of sterile and nonsterile alfalfa with or without Lactobacillus plantarum inoculant. Bioresource Technol. 2019; 275: 280-287.

Yuan X, Wen A, Dong Z, Desta ST, Shao T. Effects of formic acid and potassium diformate on the fermentation quality, chemical composition and aerobic stability of alfalfa silage. Grass Forage Sci. 2017; 72(4): 833-839.

Zhang E, Zhai W, Luo Y, Scott K, Wang X, Diao G. Acclimatization of microbial consortia to alkaline conditions and enhanced electricity generation. Bioresource Technol. 2016; 211: 736-742.

Zhang Q, Yu Z, Wang X, Tian J. Effects of inoculants and environmental temperature on fermentation quality and bacterial diversity of alfalfa silage. Anim Sci J. 2018; 89: 1085-1092.

Zhao SS, Wang YP, Yang FY, Wang Y, Zhang H. Screening a Lactobacillus plantarum strain for good adaption in alfalfa ensiling and demonstrating its improvement of alfalfa silage quality. Journal of Applied Microbiology. 2020; doi:10.1111/jam.14604

Zheng ML, Niu DZ, Jiang D, Zuo SS, Xu CC. Dynamics of microbial community during ensiling direct-cut alfalfa with and without LAB inoculant and sugar. J Appl Microbiol. 2017; 122(6): 1456-1470.

\section{Tables}

Table 1 Fermentation end-products after different Lactobacillus plantarum treatments during alfalfa ensiling 


\begin{tabular}{ccccccccc}
\hline noculant $^{1}$ & $\mathrm{pH}$ & $\mathrm{DM}$ & $\mathrm{LA}$ & $\mathrm{AA}$ & LA/AA & PA & $\mathrm{NH}_{3}-\mathrm{N}$ & WSC \\
\hline CK & $6.10^{\mathrm{a}}$ & 27.06 & $55.02^{\mathrm{c}}$ & $40.38^{\mathrm{c}}$ & $1.39^{\mathrm{a}}$ & $\mathrm{ND}$ & $10.19^{\mathrm{b}}$ & 6.47 \\
\hline LPI & $5.60^{\mathrm{b}}$ & 26.21 & $66.59^{\mathrm{b}}$ & $52.11^{\mathrm{b}}$ & $1.28^{\mathrm{b}}$ & $\mathrm{ND}$ & $11.70^{\mathrm{a}}$ & 6.3 \\
\hline LPII & $5.50^{\mathrm{b}}$ & 26.60 & $76.82^{\mathrm{a}}$ & $55.70^{\mathrm{a}}$ & $1.38^{\mathrm{a}}$ & $\mathrm{ND}$ & $7.73^{\mathrm{c}}$ & 6.94 \\
\hline$P$ & $P<0.001$ & 0.362 & $P<0.001$ & $P<0.001$ & 0.034 & - & $P<0.001$ & 0.221 \\
\hline SEM & 0.05 & 0.39 & 1.78 & 0.74 & 0.02 & - & 0.13 & 0.31 \\
\hline CK & $7.05^{\mathrm{a}}$ & $24.72^{\mathrm{b}}$ & $25.00^{\mathrm{c}}$ & $48.66^{\mathrm{ab}}$ & $0.52^{\mathrm{c}}$ & $34.87^{\mathrm{a}}$ & $15.11^{\mathrm{a}}$ & $4.30^{\mathrm{a}}$ \\
\hline LPI & $5.98^{\mathrm{b}}$ & $26.01^{\mathrm{a}}$ & $31.49^{\mathrm{b}}$ & $45.31^{\mathrm{b}}$ & $0.71^{\mathrm{b}}$ & $25.12^{\mathrm{b}}$ & $11.52^{\mathrm{b}}$ & $4.83^{\mathrm{a}}$ \\
\hline LPII & $5.67^{\mathrm{c}}$ & $26.54^{\mathrm{a}}$ & $42.13^{\mathrm{a}}$ & $50.35^{\mathrm{a}}$ & $0.84^{\mathrm{a}}$ & $20.00^{\mathrm{c}}$ & $10.42^{\mathrm{b}}$ & $3.11^{\mathrm{b}}$ \\
\hline$P$ & $P<0.001$ & 0.017 & $P<0.001$ & 0.100 & 0.001 & 0.001 & 0.001 & 0.007 \\
\hline SEM & 0.04 & 0.00 & 0.39 & 0.82 & 0.02 & 0.63 & 0.22 & 0.22 \\
\hline
\end{tabular}

Means of three observations. Values with different letters in a row indicate significant differences among treatments $(P<0.05)$.

DM, dry matter; LA, lactic acid; AA, acetic acid; LA/AA, lactic acid/acetic acid; PA, propionic acid; $\mathrm{NH}_{3}$-N, ammoniacal nitrogen; WSC, water soluble carbohydrate. \% fresh weight for DM; $\mathrm{g} / \mathrm{kg}$ of DM for $\mathrm{LA}, \mathrm{AA}, \mathrm{PA}, \mathrm{NH}_{3}-\mathrm{N}$, and WSC.

${ }^{1}$ CK, control; LPI, inoculated with L. plantarum YX; LPII, inoculated with L. plantarum A345. SEM, standard error of means.

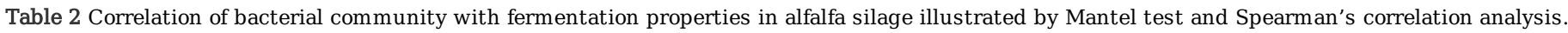

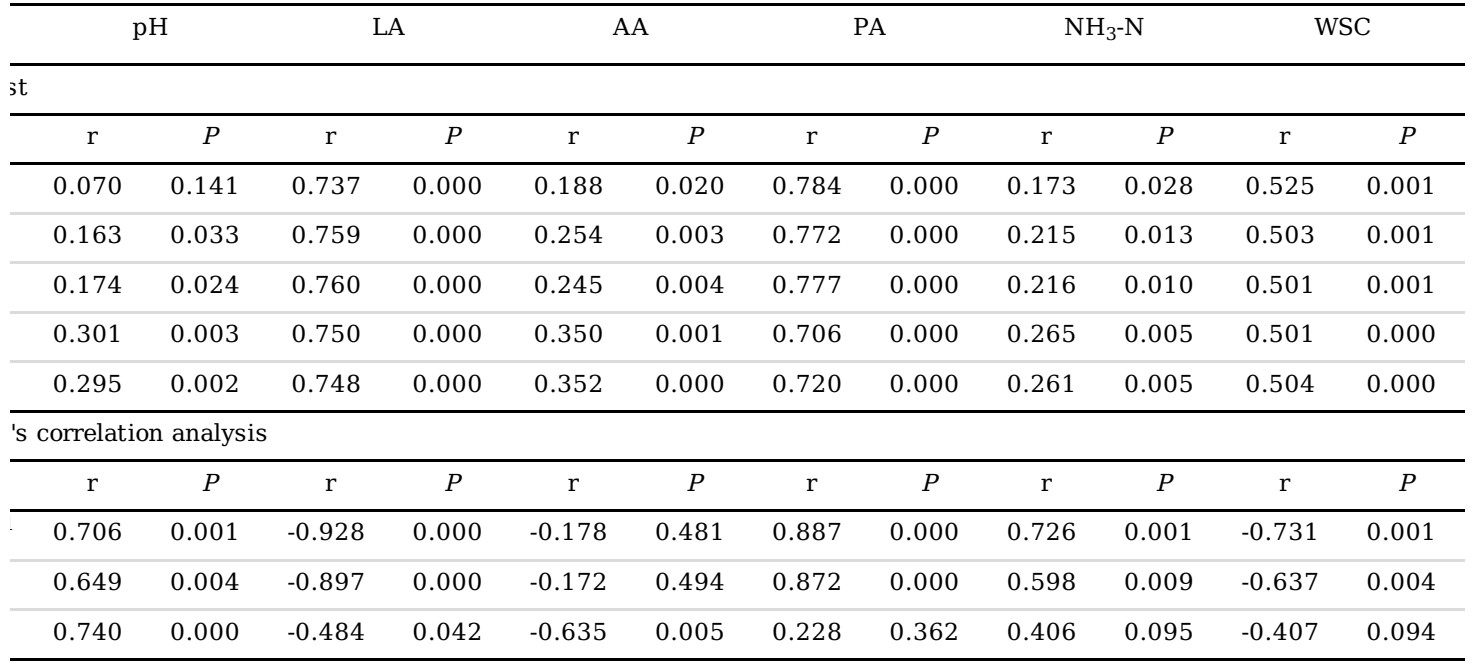

LA, lactic acid; AA, acetic acid; PA, propionic acid; $\mathrm{NH}_{3}-\mathrm{N}$, ammoniacal nitrogen; WSC, water soluble carbohydrate.

${ }^{1}$ Observed, observed bacterial species.

\section{Figures}




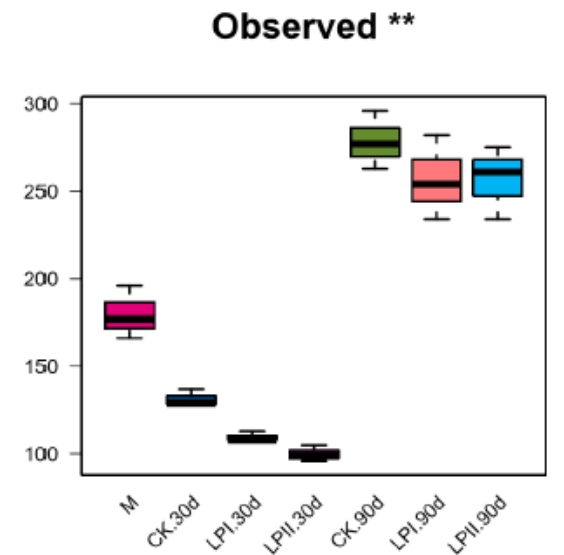

A

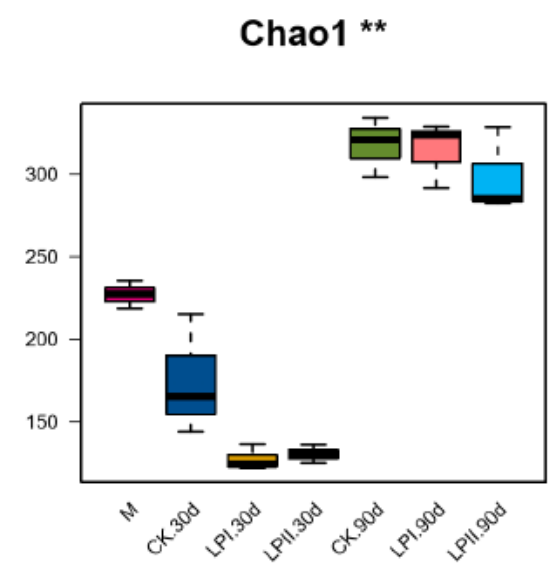

B

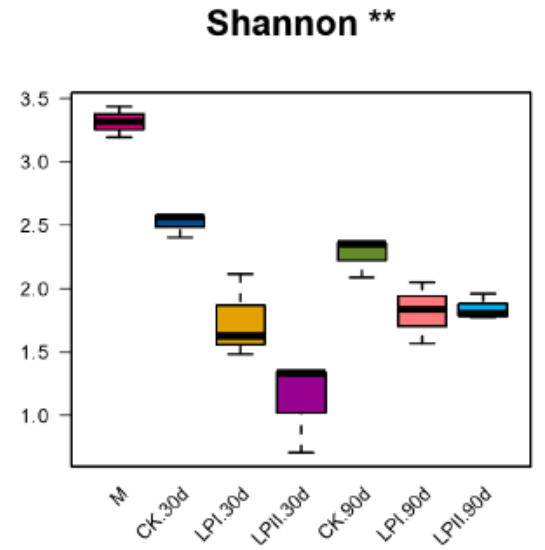

$\mathrm{C}$

\section{Figure 2}

Box-plots of observed bacterial species, Chao 1 and Shannon indices of bacterial communities in alfalfa silage. M, alfalfa material before ensiling; CK, control; LPI, inoculated with L. plantarum YX; LPII, inoculated with L. plantarum A345. The numbers following CK, LPI, and LPII stand for ensiled days of silage. Oberserved, observed bacterial species. ${ }^{*} \mathrm{P}<0.05 ;{ }^{*} \mathrm{P}<0.01$. 


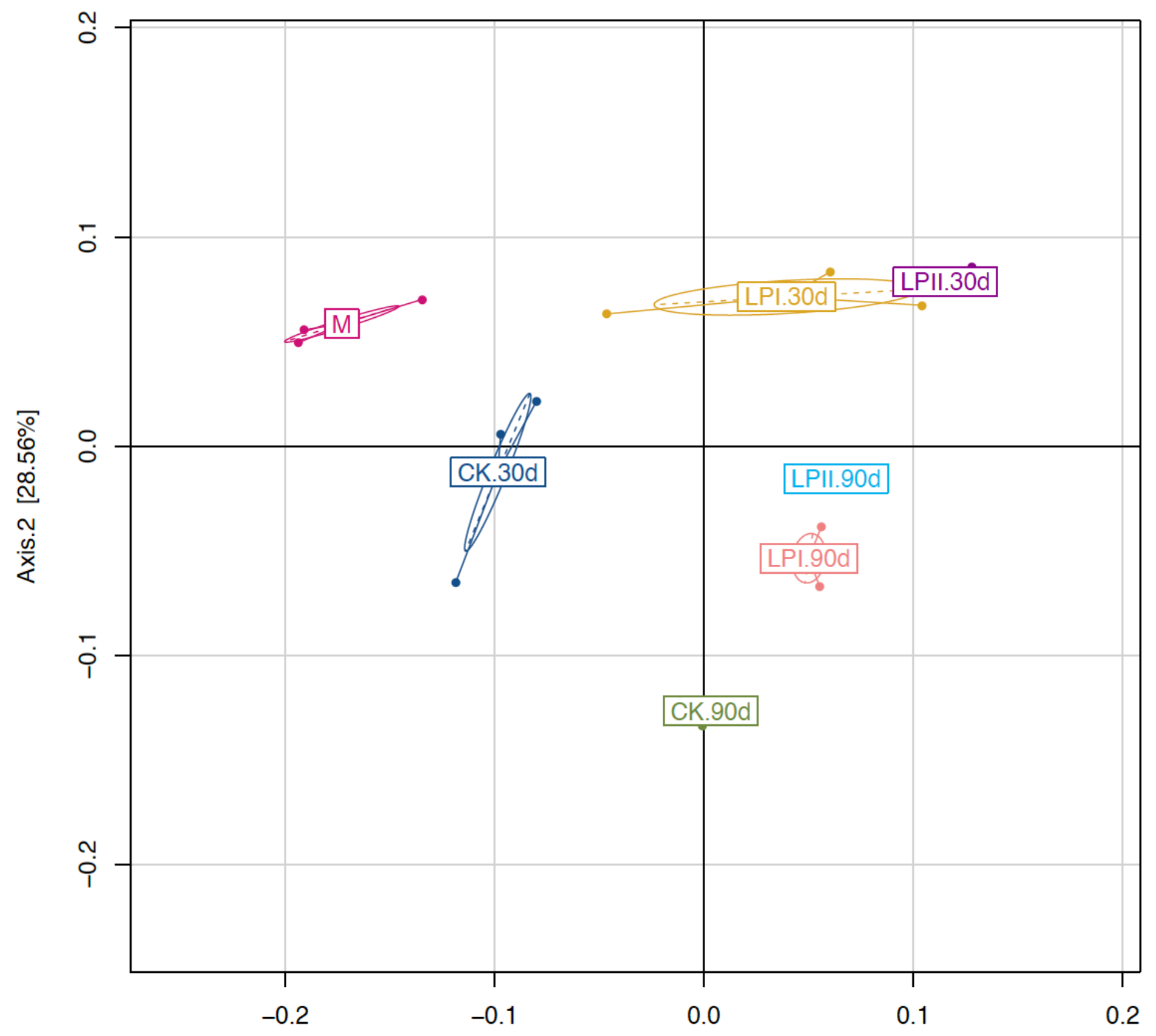

Axis. $1[52.85 \%]$

Figure 4

Cluster analysis of bacterial communities in alfalfa silage as assessed by a Principal Coordinate Analysis. M, alfalfa material before ensiling; CK, control; LPI, inoculated with L. plantarum YX; LPII, inoculated with L. plantarum A345. The numbers following CK, LPI, and LPII stand for ensiled days of silage. 

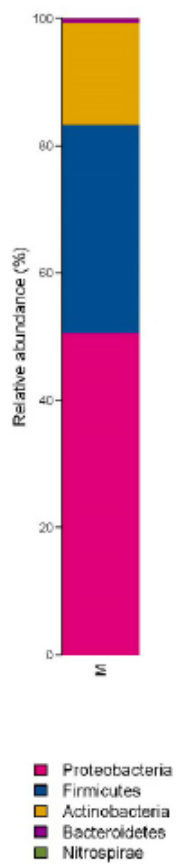

E Bacteroidetes

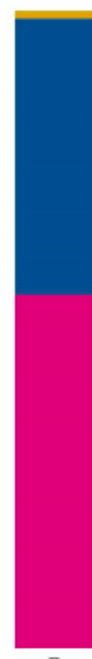

$\frac{3}{8}$
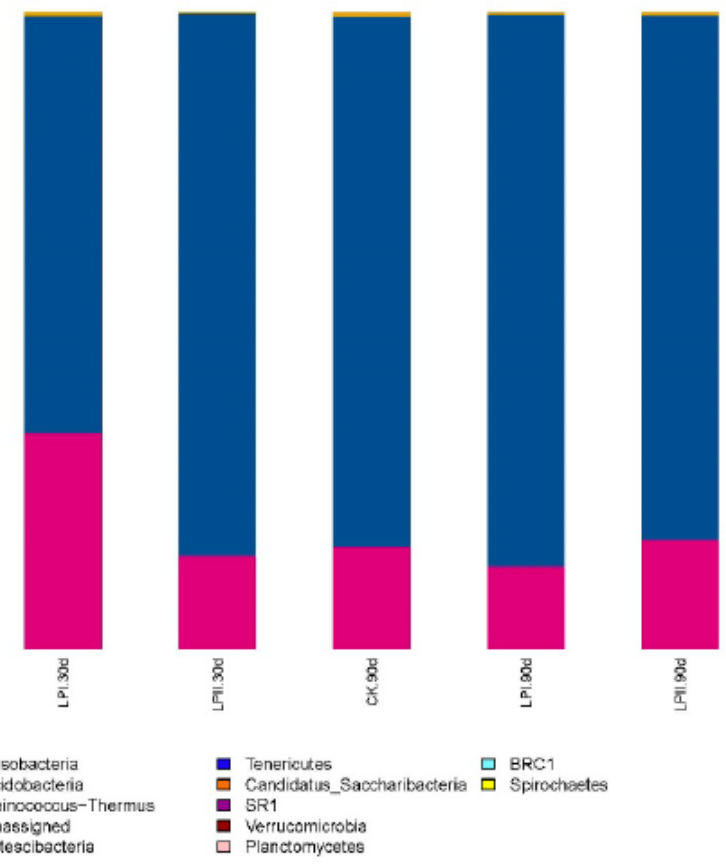

A
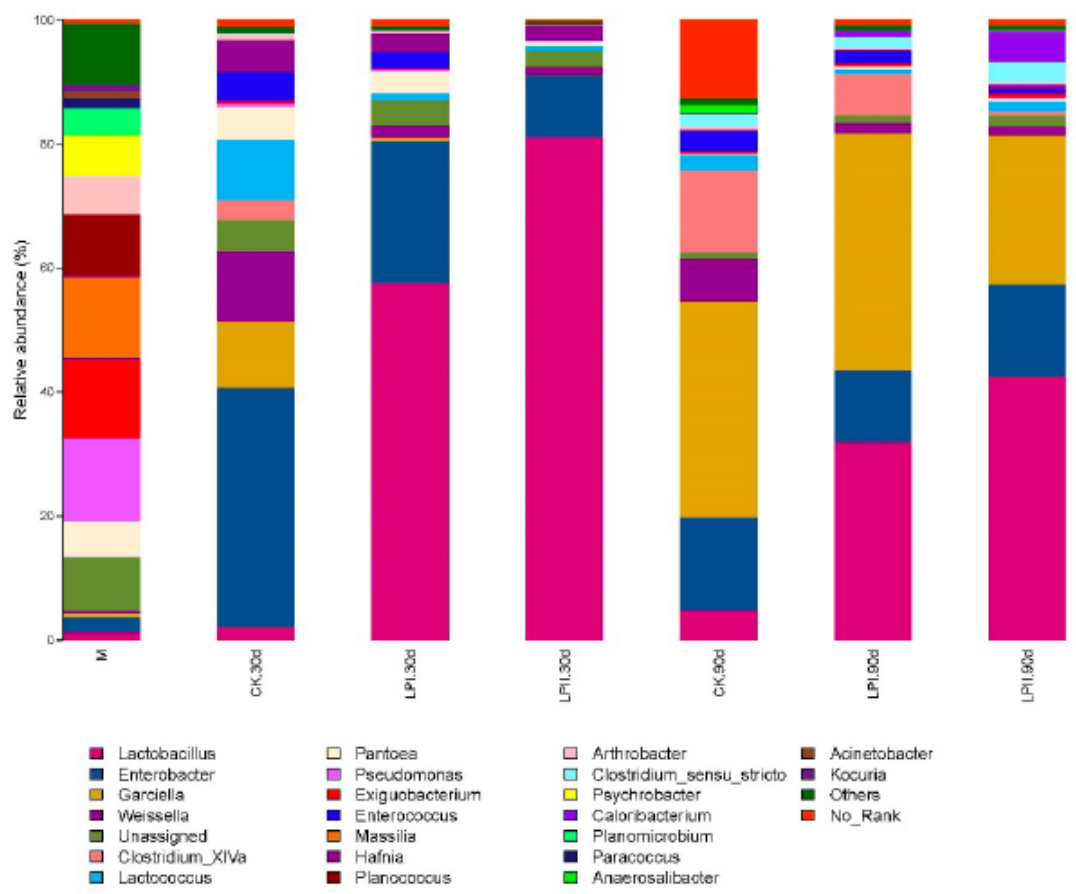

B

\section{Figure 6}

Bacterial community and relative abundances by phylum $(A)$ and genus (B) for alfalfa silage. $M$, alfalfa material before ensiling; CK, control; LPI, inoculated with L. plantarum YX; LPII, inoculated with L. plantarum A345. The numbers following CK, LPI, and LPII stand for ensiled days of silage. 


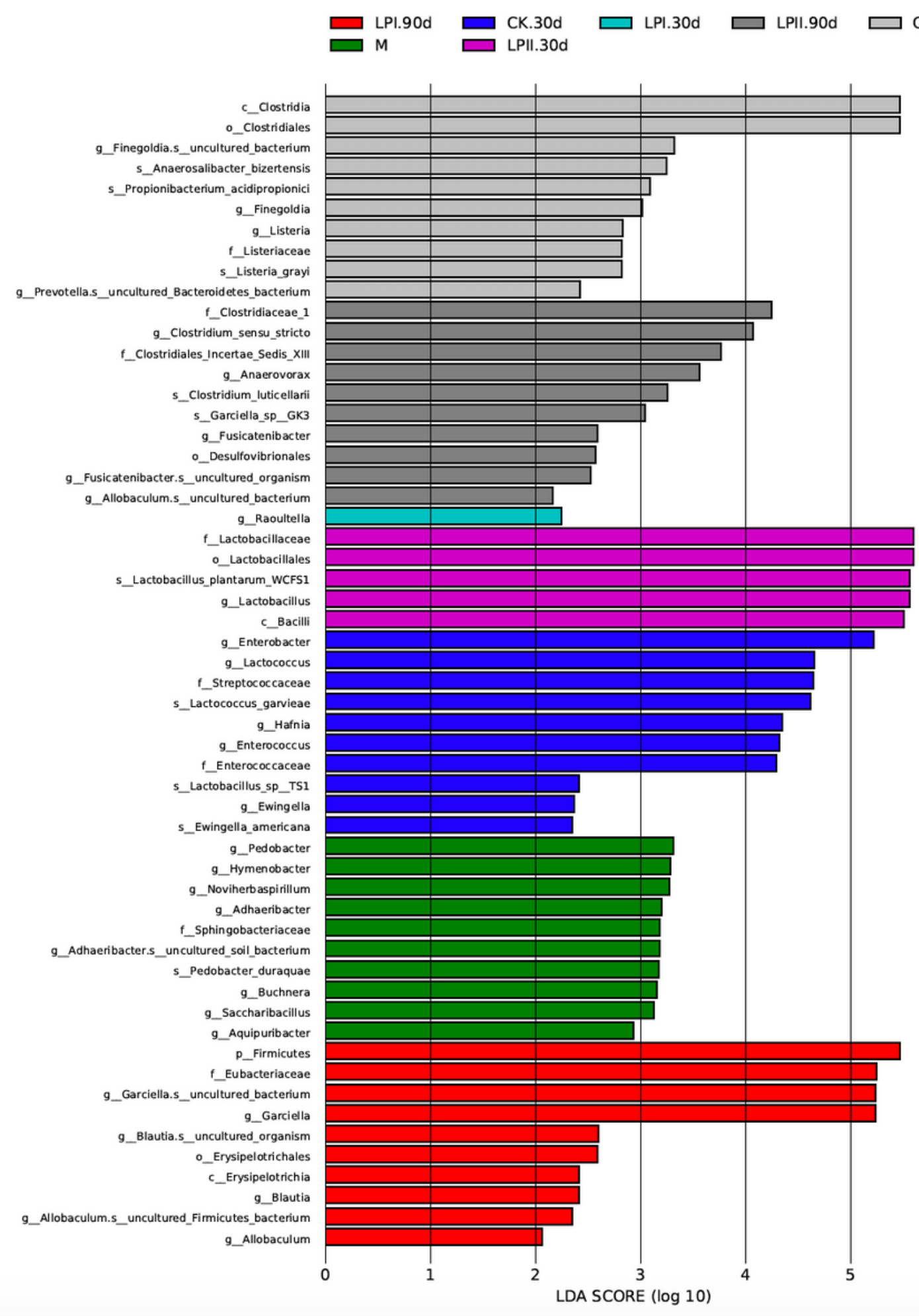

Figure 7

Comparison of microbial variations using LefSe analysis. $\mathrm{M}$, alfalfa material before ensiling; $\mathrm{CK}$, control; LPI, inoculated with L. plantarum YX; LPII, inoculated with L. plantarum A345. The numbers following CK, $\mathrm{LPI}$, and LPII stand for ensiled days of silage. 


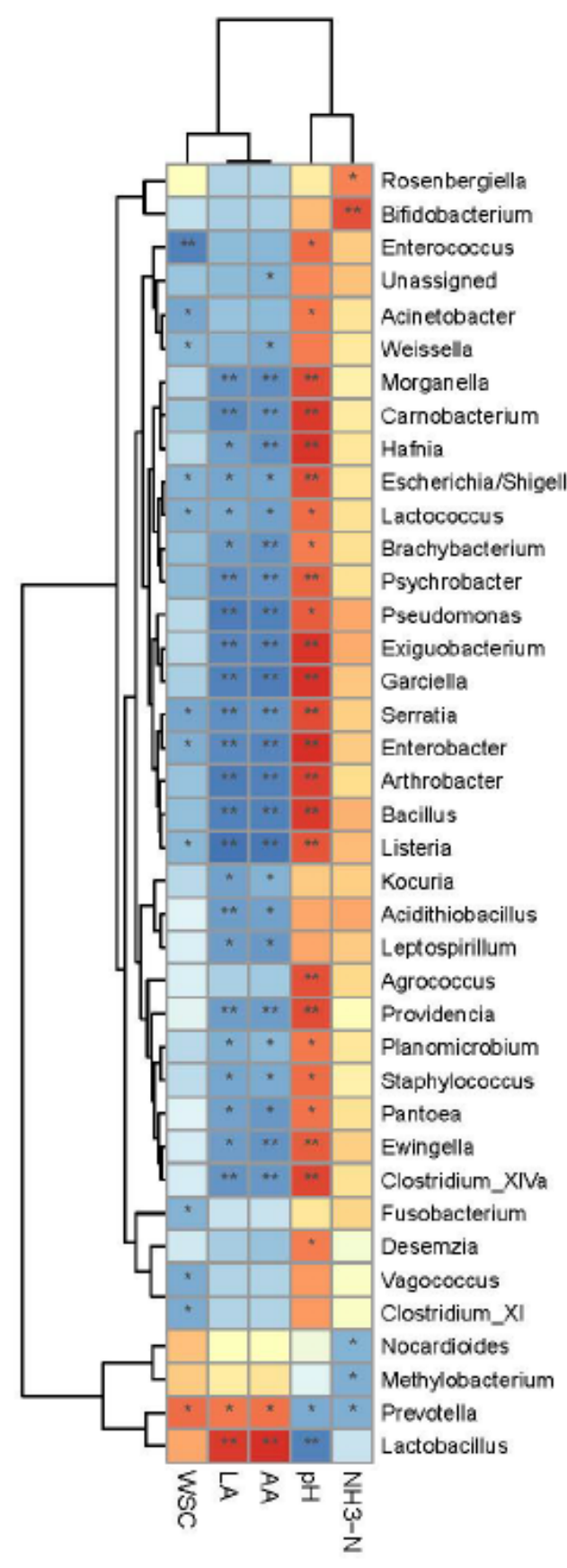

A

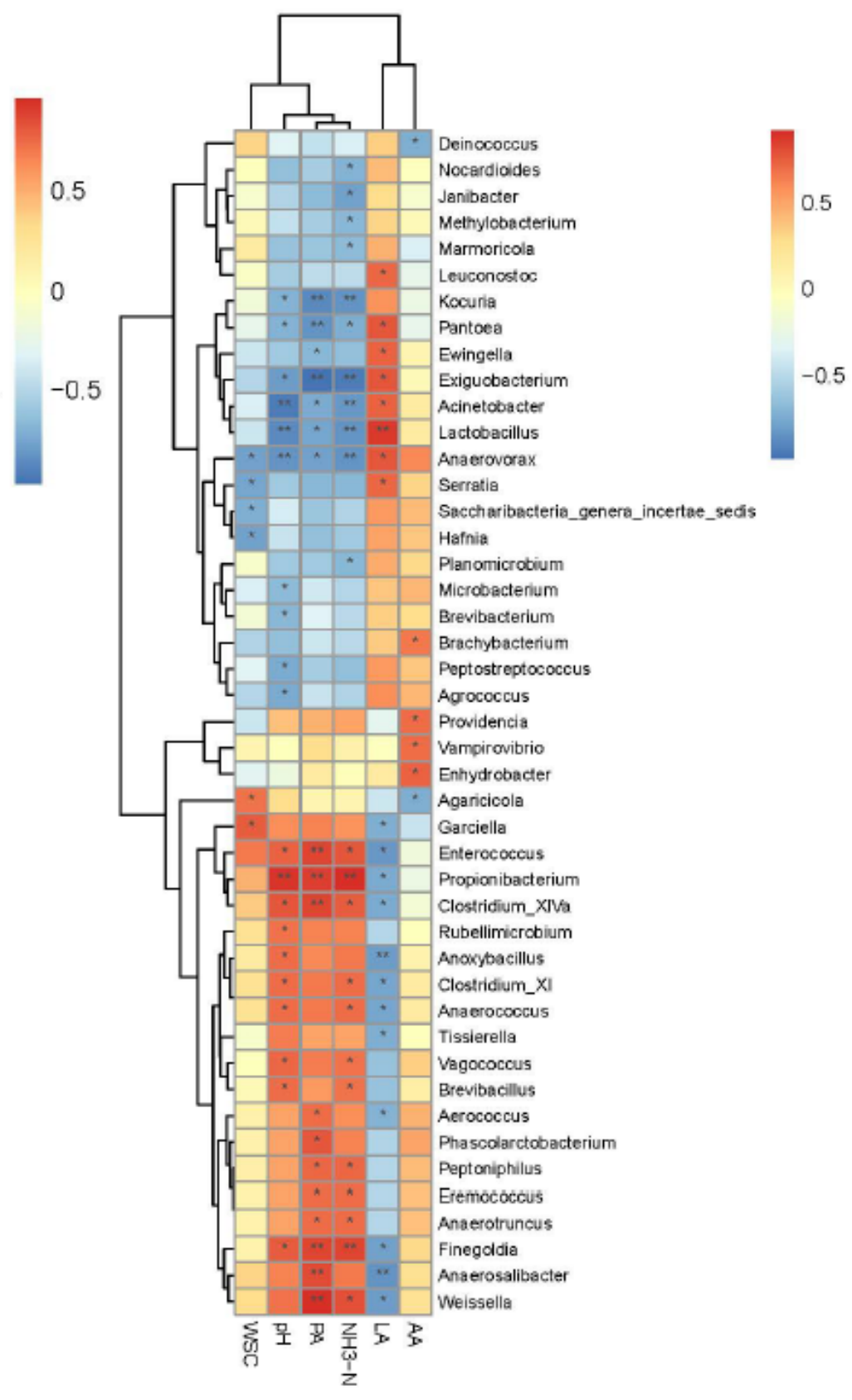

B

\section{Figure 9}

Spearman correlation heatmap of abundance of bacterial genera and fermentation properties in alfalfa ensiled for 30 days (A) and 90 days (B). LA, lactic acid; AA, acetic acid; LA/AA, lactic acid/acetic acid; PA, propionic acid; NH3-N, ammoniacal nitrogen; WSC, water soluble carbohydrate. ${ }^{*} \mathrm{P}<0.05 ;{ }^{\star \star} \mathrm{P}<0.01$. 